УДК 821.161.2.091:821.113

DOI https://doi.org/10.52726/as.humanities/2021.3.4

\author{
А. К. ДИМОВСЬКА \\ кандидат філологічних наук, \\ викладач предметно-циклової комісії української філології, \\ К3 «Балтський педагогічний фаховий коледж», м. Балта, Одеська область, Украӥна \\ Електронна пошта: annadymm@ukr.net \\ https://orcid.org/0000-0002-1300-5463
}

\title{
ПРО РЕМІНІСЦЕНЦІЇ 3 КАЗКИ Г. К. АНДЕРСЕНА «ДІВЧИНКА 3 СІРНИКАМИ» У ПОВІСТІ О. КОБИЛЯНСЬКОЇ «ЦАРІВНА»
}

У статті досліджено інтертекстуальні вкраплення з казки Г. К. Андерсена «Дівчинка 3 сірниками» в повісті О. Кобилянської «Царівна». 3 огляду на захоплення письменниці данською літературою висунуто й обгрунтовано припущення про ймовірність міжтекстової взаємодії та доцільність проведення подібних паралелей (традиційно твори О. Кобилянської вивчалися в контексті німецької та данської літератур, але без прямого зіставлення 3 текстами Г. К. Андерсена). Встановлено, що обидва тексти є інваріантами архетипної моделі сироти, архаїчні витоки якої сягають фольклорного мотиву молодшої доньки, пізніше трансформованого в європейській казці в образ пасербиці. 3'ясовано, що героїні означених творів, окрім ідентичного соціального статусу, репрезентують подібні психотипи. Визначено, що звернення О. Кобилянської до архаїчного фольклорно-міфологічного образу зумовлене психологічними комплексами й травмами авторки, які з точки зору психоаналізу сформували особливий «меланхолійний контекст» їі творчості, пов’язаний, у тому числі, з пережитими втратами дорогих людей. Проаналізовано міфологічні пласти повісті «Царівна» (античний міф про Нарциса та германські легенди про русалку Лорелей), вияви яких знайдено в особистих рисах і моделі поведінки Наталки Веркович, а також поглиблено рецепцію мотиву страдниці-сироти. Знайдено асоціативні перегуки між аналізованими творами на рівні конкретних фрагментів тексту. Виявлені приклади типологічної спорідненості потрактовано як ремінісценцію у розумінні несвідомого або мимовільного запозичення на рівнях образу, мотиву, сюжету. Крім того, увиразнено не лише подібні, а й відмінні риси поетики казки Г. К. Андерсена та повісті О. Кобилянської, зумовлені нетотожністю авторських світоглядів та інтенцій (екзистенціалізм данського казкаря та неоромантичний метод піонерки українського модернізму), гендерною, а можливо, й національною специфікою осмислення порушеної в аналізованих творах проблематики.

Ключові слова: інтертекстуальність, ремінісценція, образ, сюжет, мотив, міф, архетип.

Постановка проблеми. Відтоді, як у 1966 році Ю. Крістева ввела в науковий обіг термін «інтертекстуальність», просто неможливим стало вивчення творів словесного мистецтва поза контекстом, хоча, на думку М. Гловінського, «те, що так по-вченому було названо інтертекстуальністю, - це nihil novi sub sole - традиційна проблематика, якою займався кожен ретельний історик літератури» [Теорія 2008 : 285]. Польський теоретик усе ж визнає методологічне новаторство запропонованого Ю. Крістевою підходу, відзначаючи, що дослідник інтертекстуальності порівняно 3 істориком літератури «дивиться на своєрідне, властиве літературі від самого початку ії існування спілкування текстів 3 іншої перспективи» [Теорія $2008: 285]$, його цікавить не генезис запозичень і впливів, а їхнє значення, місце у структурі твору, роль у його семантичному наповненні. Крім того, є підстави говорити про включення до сфери інтертекстуальності лише тих зразків міжтекстових відносин, які стали «структурним / значеннєвим елементом», $\epsilon$ «навмисними», у певний спосіб «видимими», про які можна сказати, що вони «призначені для читача» [Теорія 2008 : 286-287]. Такий підхід корелює з ідеєю В. Ізера (школа рецептивної естетики) про «імпліцитного читача», який «відчуває себе втягнутим у хід подій» через процеси антиципації та ретроспекції [Антологія $2001: 353,355]$, та концепцією «відкритого твору» У. Еко, що допускає найрізноманітніші способи інтерпретації витвору мистецтва, які жодним чином не загрожують його «неповторності» [Антологія 2001 : 527]. I читач, і літературний критик із реципієнтів однаково перетворюються на співтворців художнього твору, що зумовлює безмежну кількість інтерпретацій та прочитань: «Жодне читання ніколи не може вичерпати всіх потенційних можливостей, 
оскільки кожний індивідуальний читач заповнюватиме прогалини в тексті на свій смак, вилучаючи багато інших можливостей» [Антологія $2001: 354]$.

«Література виростає з літератури», - стверджує Н. Фрай, додаючи, що «немає поета, у якого літературні впливи, що їх він зазнав, обмежуються виключно його рідною мовою» [Сучасна 2009 : 248]. Подібну думку висловлює Т. Фостер: «Діалог між старими й новими книжками відбувається весь час і на різних рівнях» [Фостер 2021 : 56]. Ж. Женетт розробив досі найуживанішу класифікацію цих рівнів, запропонувавши п'ять типів транстекстуальності (взаємодії текстів). Варто зазначити, що у теорії Ж. Женетта своєрідно переосмислено термін Ю. Крістевої: інтертекстуальність тут потрактовано лише як перший - найвужчий рівень можливої взаємодії [Genette 1999 : 117]. Утім, на думку Л. Біловус, ця класифікація не $\epsilon$ досконалою, адже в ній не враховано «різноманітні комбінації диференціальних ознак міжтекстових взаємодій» [Біловус 20036 : 22].

Аналіз попередніх досліджень. Розвиток традиції порівняльних досліджень в українському літературознавстві, започаткованих у добу Романтизму й репрезентованих працями О. Бодянського, П. Гулака-Артемовського, М. Дашкевича, М. Драгоманова, М. Костомарова, А. Кримського, І. Кронеберга, М. Максимовича, В. Масловича, О. Склабовського, I. Срезневського, I. Франка, пізніше - О. Білецького, М. Возняка, В. Перетца, В. Щурата та ін., з другої третини XX ст. бувз об' сктивних причин притлумлений та на тривалий час обмежений як просторово (переважно ареалом радянських літератур), так i функціонально (виключно 3 метою унаочнення «благотворного» впливу російської літератури на формально «нижчі» літератури «братніх» народів, стимулювання їхнього розвитку завдяки міжлітературним зв'язкам, як варіант, із літературами деяких соціалістичних країн). Хоч і з запізненням, але з 1990-х років українські дослідники «пройшли шлях від популяризації, осмислення й творчого засвоєння здобутків зарубіжних дослідників до формування власних оригінальних теоретичних концепцій» [Скорина 2019 : 71]. Л. Скорина у монографії «Гомін і відгомін: дискурс інтертекстуальності в українській літературі 1920-х років» пропонує власну періодизацію цього шляху. Так, піонерськими у вивченні категорії інтертекстуальності вважаються статті В. Агеєвої, О. Астаф'єва, М. Ткачука, дисертації Н. Корабльової, О. Троцик, І. Дітковської, А. Рубан, М. Самсонової, В. Мацапури [Скорина 2019 : 71-74]. Порушена в них проблематика, а заразом і пропонований тоді ще новаторський для українського літературознавства методологічний підхід стали поштовхом до формування потужного дискурсу інтертекстуальних студій, що витіснив на периферію наукових досліджень низку інших теоретичних питань. Другий період, маркером якого стало зростання кількості досліджень інтертексту, написаних на матеріалі української літератури [Скорина 2019 : 75], репрезентований працями Л. Біловус, С. Нахліка, М. Ізбенко, В. Просалової, О. Бердник, П. Рихла. Для сучасного етапу характерним $\epsilon$ «розширення наукової оптики» та «моделювання ефективної методології інтертекстуального дослідження» [Скорина : 81-82], тобто нині триває вельми цікавий двовекторний процес, спрямований на розвиток прикладного аспекту досліджень та водночас його теоретизацію. Ці тенденції відбито в працях М. Шаповал, Г. Віват, Л. Скорини.

Для сучасного літературознавства очевидно, що аналіз типів міжтекстової взаємодії не може бути обмежений у просторі й часі, адже будьякий текст існує поза цими категоріями, чи зведений до вивчення контактів між сусідніми літературами. Е. Касперський, посилаючись на М. Бахтіна, трактує «пограниччя в літературі» як універсальну ситуацію та зазначає, що «культура не має огороджених територій», оскільки вона «розміщується на кордонах» [Література 2008 : 537]. Таке розуміння живить компаративістику, зумовлює іiі всеохопність та пильну увагу до будь-яких літературних контактів, завдяки чому іноді виникають абсолютно неочікувані паралелі, фронтирні зони між національними літературами, значно віддаленими просторово, ментально й лінгвістично. До таких належать, у тому числі, українсько-скандинавські літературні взаємини кінця XIX - початку XX ст. Вивчаючи це питання, В. Саєнко відзначала інтенсифікацію культурного спілкування між народами, зумовлену розвитком типологічно спорідненого на європей- 
ських теренах модернізму [Саєнко 2013 : 21]. Окрім того, на думку дослідниці, «поглибленню українсько-скандинавських літературних взаємин сприяло те, що німецька й російська культури відіграли тут роль посередника» [Саєнко 2013 : 23]. Виявом українсько-скандинавських літературних взаємин у кінці XIX - на початку XX ст. стало, по-перше, «становлення скадинавістики як галузі українського літературознавства», по-друге, «прокладання плідних шляхів типологічного єднання на рівні змісту й форми» [Саєнко $2013: 23]$. Відгомін цього єднання спостерігаємо у творчості М. Коцюбинського, Лесі Українки, О. Кобилянської, В. Стефаника, I. Франка завдяки численним алюзіям, ремінісценціям, цитуванням скандинавських (данських, норвезьких, шведських) авторів - Б. Бйорнсона, Г. Брандеса, К. Гамсуна, Г. Ібсена, А. Стріндберга, С.-П. Якобсена та ін.

Дослідження інтертекстуальних вкраплень 3 казки Г. К. Андерсена «Дівчинка 3 сірниками» у повісті О. Кобилянської «Царівна» становить мету статті.

Виклад основного матеріалу. Хрестоматійно відомим є лист О. Кобилянської до О. Маковея, у якому вона називає авторитетом для себе німців [Кобилянська 1963 : 321]. Відомим також $є$ таке зізнання в автобіографіі: «Пізніше перейнялася я датською і всією нордландською літературою» [Кобилянська 1963 : 215]. Подібні вказівки самої письменниці стимулювали понад вікову традицію вивчення іiі творчості в контексті художніх пошуків скандинавських авторів (розвідки О. Маковея, Лесі Українки, І. Франка, П. Филиповича, Л. Білецького, В. Возняка, Н. Томашука, Ф. Погребенника, Я. Погребенника, М. Нагірного, Л. Гоцур, В. Саєнко, С. Кирилюк) та концепцій німецьких філософів (дослідження М. Грушевського, В. Сімовича, Л. Луціва, М. Мочульського, Т. Гундорової, Н. Зборовської, С. Павличко). I якщо суголосними для більшості з цих праць $€$ твердження про особливий вплив на естетику О. Кобилянської творів Є.-П. Якобсена та філософських трактатів Ф. Ніцше, то згадку про Г. К. Андерсена зустрічаємо лише в Л. Гоцур: «Інспірована творчістю Є.-П. Якобсена, українська письменниця залучила в сферу своїх літературних зацікавлень інших визначних представників скандинавської літератури, зокрема датських письменників Г. Банга, Г. К. Андерсена» [Гоцур 1992 : 8]. Що ж, 3 огляду на німецькомовне коло читання О. Кобилянської та іï особливий пієтет до скандинавських літератур присутність видатного данського казкаря у пантеоні авторитетів письменниці не видається випадковою. До того ж варто зазначити, що у 1873 році вийшли «Казки Андерсена 3 короткою його життєписсю» в українському перекладі М. Старицького. Отже, О. Кобилянська могла бути знайома з його казками як в оригінальних, так і в перекладних версіях.

Повість О. Кобилянської «Царівна» на рівні сюжету є інваріантом архетипної моделі сироти, архаїчним первнем якої $\mathrm{C}$. Мелетинський вважає фольклорний мотив молодшої доньки, пізніше трансформований у європейській казці в образ пасербиці [Мелетинский 2005 : 139]. Традиційна для світової літератури фабула (Ш. Бронте «Джейн Ейр», Е. Гаскелл «Мері Бартон», Дж. Остен «Гідність і гонор», Р. Н. Гюнтекін «Чаликушу» еtc.) одного з перших творів молодої авторки репрезентує тривіальну, на думку, скажімо, М. Грушевського, модернізацію старої історії про Попелюшку «у формі жіночого щоденника» [Грушевський 1898 : 174]. I. Франко, у цілому позитивно відгукуючись про творчість О. Кобилянської, знаходить у «Царівні» ряд недоліків (довільну композицію, «неясність» ідейного змісту тощо). Однак авторитетний критик називає іiі ранні твори «свіжим подихом повітря» у «новітній українській літературі» [Франко 1986 : 282]. Через століття С. Павличко різко критикує рецепцію творів (зокрема, «Царівни») О. Кобилянської сучасниками, у тому числі й І. Франком: «Це була проза, що ілюструвала й обстоювала певні нові ідеї, зокрема ідеї емансипації й фемінізму. <..> Критики, які їх не хотіли помічати, зробили це цілком свідомо» [Павличко 1999 : 71]. Дослідниця наполягає, що неприйняття запропонованого Кобилянською образу емансипованої «нової» жінки українською чоловічою критикою зумовлене почасти гендерними упередженнями, страхом перед зазіханнями жінок-письменниць на «домінуючу чоловічу традицію», адже у повістях «Людина» $\mathrm{i}$ «Царівна» виразно прописано опозицію «сильні жінки - слабкі чоловіки» [Павличко 1999 : 69]. Нехай сюжет і форма 
повісті «Царівна» справді не претендують на новаторство, але головна іiі героїня є зразком малорозвиненого в українській літературі другої половини XIX ст. типу жінки-переможниці, що підкорила собі обставини, проте не в традиційному потрактуванні, відбувшись водночас і як письменниця, і як дружина.

Повернімось до питання про сирітський архетип, репрезентований у «Царівні». 3 точки зору психоаналізу звернення авторки до цього архаїчного образу зумовлене не так тяжінням до традиційних сюжетів, як власними психологічними комплексами й травмами. Т. Гундорова у монографії «Femina Melancholica. Стать і культура у гендерній утопії Ольги Кобилянської» (2002) пропонує розглядати творчість О. Кобилянської крізь призму особливого «меланхолійного контексту», породженого втратами дорогих людей (у тому числі, матері), розчаруванням в ідеалах [Гундорова 2002 : 10-11]. Прикрих речей, як відомо, на долю письменниці випало чимало.

Ю. Крістева у відомій психоаналітичній праці «Чорне сонце. Депресія та меланхолія» (1987) називає меланхолію «блідою супутницею кохання», викликаною втратою Іншого, закоріненою у травмах, за якими «не завершено жалоби» [Кристева 2016 : 10-12]. Такою меланхолійною тугою за втраченими родичами позначено героїнь повісті О. Кобилянської «Царівна» та казки Г. К. Андерсена «Дівчинка 3 сірниками».

Наталка Веркович - сирота, яка після смерті батьків та бабусі знайшла прихисток у дядька по матері. Живучи в їхньому домі як «одна з тих, над котрими добрі люди повинні і без любові мати милосердя» [Кобилянська 1988 : 29], вона постійно відчувала зверхність і неприязнь з боку тітки та ії дітей: «Всі вони мені не раді. Відчула й пізнала я це 3 тої хвилини, в котрій лише зачала думати. Моє довге рудаве волосся давало кузинам та кузинкам причину до прикрих глумливих жартів та сміху. Лице моє їм «закрейдяне», а очі? Боже! наче я тому винна, що вони для них завеликі?» [Кобилянська 1988 : 24]. Не маючи спорідненої душі, з якою могла б ділитися своїми печалями, Наталка у найгірші хвилини згадувала покійну бабусю, подумки розмовляла 3 нею: «- Бабуню! питала я раз. - Чому ви якось-то казали, що вам на мій вид накидується насилу думка, буцімто я до терпіння вродилася, і що коли я родилася, жебраки та якісь убогі у дім, наче кликані, заходили і просили то молока, то хліба, то грошей; це, казали ви, злий знак на будуче, не буду щастя мати... Бабуню! «Терпіти» - значить то, як когось щось дуже болить? <..> Бабусенько моя золота!» [Кобилянська 1988 : 25]; «Бабуню, бабусенько моя золота, чом ти мене покинула! - кликала я там в розпуці раз по раз... - Бабуню, бабуню... я камінь! Бабусенько моя дорога, я одна 3 тих, над котрими добрі люди мусять і без любові мати милосердя!..» [Кобилянська 1988 : 30]. Згадувала дівчина й померлих батьків: «Я думала про померших родичів, про бабуню і про те, що вона мені завсігди об них оповідала. Приміром, як не раз радилися над моєю долею. Я була в них лише одна-однісінька, тому мало все добро світу мені припасти. Батько пестив мене, майже не випускав з рук, а мати розпадалася...» [Кобилянська 1988 : 103]. Послуговуючись термінологією Ю. Крістевої, зазначимо, що Наталка свідомо не завершує своєї жалоби, тримаючись за метафізичний зв'язок з померлими, що зумовлює іiі меланхолійне споглядання власного минулого, ідеалізацію втрачених дорогих людей, пасивне (до певного моменту) упокорення й прийняття свого становища.

Зауважимо, що Ю. Крістева пов'язує комплекс меланхолійності з міфом про Нарциса, чиє переживання туги за втратою (чи пак неможливістю заволодіти бажаним) знаходить вияв у самозамилуванні [Кристева 2016 : 11]. Прикметно, що Наталка на початку твору, комплексуючи через постійні негативні зауваження на свою адресу, «не дивилася майже ніколи в дзеркало» [Кобилянська 1988 : 25]. Але в міру вивільнення іiї особистості з лабет міщанської задухи в тексті з'являється низка епізодів, у яких молода красуня милується собою, а їі самоспоглядання набуває відверто нарцисичного відтінку. Цілком прозорою видається, скажімо, алюзія, представлена в описі прогулянки Наталки. Ідучи містом, дівчина зупиняється в парку над ставом: «Вода мала для неї незрозумілу притягаючу силу. Вона сперлася о штахети і споглядала з задумливою цікавістю на гладку, нерухому, дзеркальну площу $<\ldots>$ вона розіпнула пальто. Опісля зігнулася 
глибше над водою і в такій поставі якийсь час дивилася в глибінь < ..> Нараз помітила себе. Чи так виглядала вона? Чорний жалібний стрій і довга крепа, спадаючи з капелюха аж до землі, робили іiі ще вищою. Однак іiі обличчя видавалося їй іншим, як звичайно. Великі блискучі очі дивилися 3 лиця так спокійно, однак заразом так вижидаюче! Чого вони ожидали, чого? < ..> На час прижмурила очі, мовби боялася, щоби то раювання ії душі не згубилося через якесь інше враження. Їй було так мило і гарно тепер... саме, саме тепер... Коли створила по хвилині очі і побачила свій власний

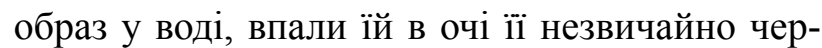
воні уста. «Я гарна!» - заговорив в ній якийсь голос. «Так», - і вона почала приглядатися собі. Вона була дійсно гарна. Сніжно-біла, а до того великі, як сталь сіяючі очі. Стать іiі була гнучка і струнка, отже, була цілком гарна, в тій хвилині навіть дуже гарна... «Царівна», - навинулось їй на думку» [Кобилянська 1988 : 264-266]. Порівняймо наведений уривок з німим захопленням Нарциса в Овідієвих «Метаморфозах»: «Ось він завмер, наче різьблений мармур пароський, Зором холодним красу свою п'є, та напитись не може. Очі свої, дві зорі, й волосся, яким не гордив би Вакх, або й сам Аполлон, лежачи над водою, він бачить. < ..> жадливо п'є безтілесну красу, в незворушну задивлений воду» [Овідій 2020 : 103]. Врода Наталки надзвичайно жіночна, але й дещо екзотична - руде волосся, великі очі, високий зріст. О. Кобилянська взорує її за німецьким міфом про одну з дів Райну русалку Лорелей, надзвичайна краса й чарівний голос якої вабили рибалок, котрі, милуючись, втрачали обережність і розбивались об скелі [Одоевцева 1998 : 232]. Як і Нарцис - самозакоханий юнак із давньогрецького міфу, русалка, сидячи на скелі, полюбляє милуватися собою. Але обидва ці міфічні персонажі нещасливі, їхня краса стає прокляттям: жоден 3 них «дотягтись до любові не зможе» [Овідій 2020 : 102]. В образі Наталки Веркович переплітаються антична та германська міфології, поглиблюючи архаїчний мотив страдниці-сироти.

Соціальне становище дівчинки з сірниками 3 казки Г. К. Андерсена вельми подібне до Наталчиного: напівсирота, що живе в страшних злиднях, вона позбавлена крихти батьківської любові, а в останній вечір старого року (у пере- кладі М. Старицького вжито еквівалентну конструкцію «на Меланки» [Андерсен 2017 : 285]) змушена продавати сірники на вулицях великого міста. Заклопотані святковими справами перехожі не звертають уваги на вбрану в завеликі материні черевики дівчинку, вочевидь, сприймаючи іiї як жебрачку (тут, можливо, відіграє роль також традиційне для протестантської культури негативне ставлення до жебраків, які з Божої ласки перебувають у злиденному становищі, у якому не може опинитися вірний християнин). Дівчинка боїться повертатися додому, адже їй не вдалося нічого продати. У стані цілковитого відчаю вона, зрештою, починає запалювати сірники, щоб хоч трохи зігріти застиглі кінцівки, i тоді іï охоплюють дивовижні візії, у яких втілено такі прості й безпосередні потреби: тепла груба, святковий стіл з наїдками, новорічна ялинка. Коли 3 неба впала зірка, дівчинка знову черкнула сірником - i $з$ полум'я виринув образ її покійної бабусі «з таким ясним обличчям, 3 таким щирим поглядом». Дорога небіжчиця узяла дівчинку на руки, «і обидві, осяяні світом, радісно полинули вгору високовисоко - туди, де нема ні холоду, ні голоду, ні туги - полинули до самого Бога!» [Андерсен $2017: 288]$. У хвилину розпачу й безнадії спрацьовує описаний Ю. Крістевою механізм незавершеної жалоби за бабусею («котра тільки й любила її щиро» [Андерсен 2017 : 288]), що ним було зумовлено меланхолійний характер дівчинки, яка воліла загинути на вулиці, аніж повертатися на холодне горище, де чекав на неї жорстокий батько.

Недарма критики називають цю казку пародією на різдвяне оповідання [Зарубіжні 2005 : 39]: уранці першого дня нового року черстві та байдужі жителі міста знаходять на вулиці тіло замерзлої сирітки. Означений фрагмент казки перегукується із повістю О. Кобилянської «Царівна» на інтертекстуальному рівні у формі ремінісценції. Застосування цього терміна передбачає усвідомлення відсутності його чіткого та однозначного потрактування. Приміром, Л. Скорина виокремлює п’ять ключових підходів до визначення терміна: 1) ремінісценція як родове поняття, що включає цитати й алюзії; 2) ототожнення ремінісценції з неусвідомленою інтертекстуальністю; 3) ремінісценція як структурне наслідування прототексту; 
4) ремінісценція як різновид цитати чи алюзії; 5) ремінісценція як стилістичний прийом [Скорина 2019 : 132-133]. За основу своєї студії дослідниця бере таке тлумачення: «Ремінісценція - це форма інтертекстуальності, що вказує на зв'язок твору 3 позатекстовою дійсністю (історією, культурою, біографією автора» [Скорина $2019: 134]$.

Для нашої розвідки найбільш методологічно доцільним $є$ уявлення про інтертекстуальність як «здатність твору асоціюватися 3 іншими творами» [Біловус 20036 : 25], вислі- дом якого є розуміння ремінісценції, запропоноване Л. Біловус: «образи літератури в літературі», що «виявляють єдність і внутрішню співвіднесеність зовні несхожих явищ» [Біловус 2003a : 43-44]. Власне, на такому - асоціативному - рівні базується зіставлення казки Г. К. Андерсена з повістю О. Кобилянської, яке дозволило оприявнити спільне міфологічне підгрунтя (архетип сироти-Попелюшки, міф про Нарциса) їхньої образності й сюжету. Наведемо конкретний приклад текстового рівня відгомону Андерсенової казки у повісті О. Кобилянської.

\section{Г. К. Андерсен «Дівчинка $з$ сірниками»} (переклад М. Старицького)

\section{О. Ю. Кобилянська «Царівна»}

«... другого зимнього ранку, у куточку між «Вона хотіла би відійти саме перед сходом сонця. Була двох будинків, маленька дівчинка усе ще би бажала потонути лицем у квіти, коли б тепер які були. сиділа з почервонілими щічками, з люб'язною В безчисленні й різнобарвні, солодко пахучі, майже упоюючі усмішкою, - тільки вже одубла й замерзла. квіти, як рожі, лелії, боз, астри і багато-багато інших. До їі Зійило холодне сонце на Новий рік й осяяло слуху міг би долітати бренькіт бджіл. Але не тонесенький, дівчинку з ї̈ сірниками» (курсив наш-A. Д.). журливий, що накликує насилу тугу в серце, лиш той [Андерсен $2017: 288-289]$.

голосний, повнозвучний бренькіт роя бджіл, бренькіт, що нагадує ясні весняні дні і теплий, квітами садовими переповнений воздух. А відтак - вже по всім нехай би зійшло сонце, велично, пророчо і нехай би цілою своєю пишнотою і всім багатством свого блиску - поцілувало ііі.

Рано зійшло сонце велично, пророчо $і$ цілою пишнотою, цілим багатством свого блиску цілувало ії. Але не мертву (курсив наш $-A$. Д.). Вона стояла, як учора рано, закинувши сплетені руки поза голову, обгорнена чудовим волоссям своїм, що сягало аж до землі, і дивилася широко створеними очима кудись у далечину» [Кобилянська 1988 : 304-305].

Разючою видається подібність наведених уривків. Після кульмінації, у якій кожна героїня робить свій екзистенційний вибір - жити чи не жити, в обох творах розв'язка настає вранці, коли сходить сонце й починається новий день, аби освітити в одному випадку мертве тіло загиблої дитини, відторгненої безсердечним суспільством, а в другому - «царівни» своєї долі, такої ж сироти, яка вступає в боротьбу з немилосердним світом, аби перемогти й досягти визначеної мети: «Буду жити, <..> і йти тою самою дорогою, що досі. Це неможливо, щоб я не побідила, або щоб надо мною панувало що інше, як сама краса життя» [Кобилянська 1988 : 305]. На відміну від трагічного сюжету данської літературної казки, архетипний зв'язок якої 3 «Попелюшкою» та їі архаїчними прототипами не викликає сумнівів, повість О. Кобилянської репрезентує неоромантичне осмислення традиційного образу, вивищення героїні не лише над суспільством (у соціальному чи матеріальному плані), а й над власною слабкістю.
Висновки. Невідомо, чи була знайома О. Кобилянська $з$ текстом «Дівчинки $з$ сірниками» Г. К. Андерсена, а якщо й була, то з оригіналом чи з перекладом. Однак маємо вже цитовану автобіографію письменниці про вплив на неї цілої данської літератури (не самого тільки Якобсена!). Це дає підстави говорити про ймовірність прямих інтертекстуальних зв'язків на рівні ремінісценції як асоціативного співвіднесення (несвідомого або мимовільного запозичення між означеними текстами), а також про обгрунтованість проведення паралелей між творчістю двох майстрів, здавалося б, таких далеких, але, як свідчать бодай наведені уривки, типологічно таких споріднених літератур, як українська й данська. «Царівна» О. Кобилянської та «Дівчинка з сірниками» Г. К. Андерсена $є$ зразками засвоєння та інтерпретації (хай у різних жанрових формах) того ж самого архаїчного сюжету, який стає спільним контекстним знаменником і підставою для їх зіставлення. Героїні цих творів, окрім ідентичного соціаль- 
ного статусу, репрезентують подібні психотипи: втрата найдорожчих людей, обставини сирітського дитинства формують меланхолійне світосприйняття й хворобливий нарцисичний комплекс, спровокований жагучим прагненням любові й тепла від ближніх. Однак відмінний фінал виявляє нетотожність авторських світоглядів та інтенцій (екзистенціалізм знаного данського казкаря та неоромантичний запал молодої української авторки, якій ще тільки належало вибороти собі місце «пишної троянди в саду української літератури»), гендерну, а можливо, національну специфіку осмислення порушеної в аналізованих творах проблематики (адже Наталка Веркович - не лише «царівна» своєї долі, цей образ знаковий і в контексті уявлень О. Кобилянської про українську національну боротьбу; це, зрештою, неактуальне для Г.К. Андерсена питання, адже Данія з VIII ст. мала статус самостійного королівства). Намічений вектор подальших досліджень сприятиме не лише розширенню обріїв вивчення українсько-скандинавських літературних зв'язків, айпоглибленнюрецепціїтворівО.Кобилянської.

\section{ЛІТЕРАТУРА}

1. Андерсен Г. К. Казки / пер. з датської і передм. О. Іванченко. Харків : Фоліо, 2017. 347 с.

2. Антологія світової літературно-критичної думки XX ст. / за ред. М. Зубрицької : 2-е вид., доповнене. Львів : Літопис, 2001. $832 \mathrm{c}$.

3. Біловус Л. І. Інтертекстуальність як модус новаторства (на матеріалі творчості В. Стуса та І. Світличного) : дис. ... канд. філол. наук : 10.01 .06 ; Тернопільський державний педагогічний університет ім. В. Гнатюка. Тернопіль, 2003. $173 \mathrm{c.}$

4. Біловус Л. Теорія інтертекстуальності: становлення понять, тлумачення термінів, систематика. Тернопіль, 2003. $36 \mathrm{c}$.

5. Гоцур Л. В. Ольга Кобилянська в українсько-німецьких літературних взаєминах : автореф. дис. ... канд. філол. наук : 10.01.03. Київ, 1992. 18 с.

6. Грушевський М. «Царівна». Літературно-науковий вісник. 1898. Т. 1. Кн. 3. С. 174-180.

7. Гундорова T. Femina Melancholica: стать і культура в гендерній утопії Ольги Кобилянської. Київ : Критика, 2002. $272 \mathrm{c}$.

8. Зарубіжні письменники: енциклопедичний довідник : у 2 т. Т. 1 : А-К / за ред. Н. Михальської та Б. Щавурського. Тернопіль : Навчальна книга - Богдан, 2005. 824 с.

9. Кобилянська О. Ю. Твори : в 2 т. Т. 1 : Царівна : повість ; оповідання / упоряд., авт. передм. та приміт. Ф. П. Погребенник. Київ : Дніпро, 1988. 541 с.

10. Кобилянська О. Твори : у 5 т. Т. 5. Київ : Держлітвидав України, 1963. 767 с.

11. Кристева Ю. Черное солнце: депрессия и меланхолия / пер. с фр. Москва : Когито-Центр, 2016. 276 с.

12. Література. Теорія. Методологія / пер. $з$ польськ. С. Яковенка ; упорядкув. і наук. ред. Д. Уліцької ; 2-ге вид. Київ : Вид. дім «Києво-Могилянська академія», 2008. 543 с.

13. Мелетинский Е. М. Герой волшебной сказки. Москва ; Санкт-Петербург : Академия исследований культуры, традиций, 2005. 240 с.

14. Одоевцева И. Лорелея. Энциклопедия литературных героев. Москва, 1998. С. 232-233.

15. Павличко С. Дискурс модернізму в українській літературі : монографія : 2-ге вид., перероб. і доп. Київ : Либідь, 1999. 447 с.

16. Публій Овідій Назон. Метаморфози / переклав з латини А. Содомора ; 4-е видання. Львів : Видавництво «Апріорі», 2020. 520 с. : іл.

17. Саєнко В. 3 українсько-скандинавських літературних взаємин: О. Кобилянська і Є.-П. Якобсен. Слово і Час. 2013. № 11. C. 19-30.

18. Скорина Л. «Гомін і відгомін»: дискурс інтертекстуальності в українській літературі 1920-х років : монографія. Черкаси : Брама-Україна, 2019. 704 с.

19. Сучасна літературна компаративістика: стратегії і методи. Антологія / за заг. ред. Д. Наливайка. Київ : Видавничий дім «Києво-Могилянська академія», 2009. 487 с.

20. Теорія літератури в Польщі. Антологія текстів. Друга половина XX - початок XXI ст. / упоряд. Б. Бакули; зазаг. ред. В. Моренця ; пер. зпольськ. С. Яковенка. Київ : Видавничий дім «Києво-Могилянська академія», 2008. $531 \mathrm{c}$.

21. Фостер Т. Как читать художественную литературу как профессор: проницательное руководство по чтению между строк / пер. с англ. Т. В. Камышниковой, М. П. Сухотиной. Москва : КоЛибри, Азбука-Аттикус, 2021.368 с.

22. Франко І. Твори : в 50 т. Т. 50. 1986. С. 281-282.

23. Genette G. Palimpsesty. Literatura drugiego stopnia. Teoria $i$ metodologia badań literackich. Warszawa : Universytet Warszawski, 1999. S. 107-154. 


\section{REFERENCES}

1. Andersen, H. Ch. (2017). Kazky: per. $z$ datskoi [Fairy tales: translated from Danish]. Kharkiv : Folio [in Ukrainian].

2. Zubrytska, M. (Ed.) (2001). Antolohiia svitovoi literaturno-krytychnoi dumky XX stolittia [Anthology of world literary and critical thought of the twentieth century]. Lviv : Litopys [in Ukrainian].

3. Bolivus, L.I. (2003). Intertekstualnists yak modus novatorstva (na materiali tvorchosti V. Stusa ta I. Svitlychnoho) [Intertextuality as a mode of innovation (based on the works of V. Stus and I. Svitlychnyi]. (Candidate's thesis). V. Hnatiuk Ternopil State Pedagogical University. Ternopil [in Ukrainian].

4. Bilovus, L. (2003). Teoriia intertekstualnosti: stanovlennia poniat, tlumachennia terminiv, systematyka [Theory of intertextuality: formation of concepts, interpretation of terms, systematics]. Ternopil, Vydavets Starodubets [in Ukrainian].

5. Hotsur, L. V. (1992). Olha Kobylianska v ukrainsko-nimetskykh literaturnykh vzaiemynakh [Olha Kobylianska in Ukrainian-German literary relations]. (Extended abstract of candidate's thesis). M.P. Drahomanov Kyiv State Pedagogical Institute [in Ukrainian].

6. Hrushevskyi, M. (1898). "Tsarivna”. Literaturno-naukovyi visnyk. Vol. 1, b. 3.174180 [in Ukrainian].

7. Hundorova T. (2002). Femina Melancholica: Stat i kultura v gendernii utopii Olhy Kobylianskoi [Femina Melancholica: Gender and culture in Olga Kobylyanska's gender utopia]. Kyiv : Krytyka [in Ukrainian].

8. Mykhalska N., Shchavurskyi B. (Ed.). 2005. Zarubizhni pysmennyky. Entsyklopedychnyi dovidnyk [Foreign writers. Encyclopedic reference book]. Vol. 1: A-Kobylianska, O. Yu. (1988). Tvory: V 2 t. T. 1.: Tsarivna [Works: in 2 volumes. Vol. 1: Tsarivna]. K. : Dnipro [in Ukrainian].

9. Kobylianska, O. (1963). Tvory: V 2 t. T. 5. [Works in 5 volumes. Vol. 5]. Kyiv: Derzhlitvydav Ukrainy [in Ukrainian].

10. Kristeva, Yu. (2016). Chernoe solntse: Depressiya i melanholiya [Black Sun: Depression and Melancholy]. M.: Kogito-Tsentr [in Russian].

11. Ulitska, D. (Ed.). 2008. Literatura. Teoriia. Metodolohiia [Literature. Theory. Methodology]. $2^{\text {nd }}$ edition. (S. Yakovenko, Trans.). K. : Vydavnychyi dim "Kyievo-Mohylianska akademiia" [in Ukrainian].

12. Meletynskyi, E.M. (2005). Geroy volshebnoy skazki [Hero of a fairy tale]. M.:-Odoevtseva I. (1998). Loreleya [Lorelei]. Entsiklopediya literaturnyih geroev [Encyclopedia of literary characters]. Moscow [in Russian].

13. Pavlychko, S. (1999). Dyskurs modernizmu v ukrainskii literature [Discourse to modernism in Ukrainian literature]. K. : Lybid [in Ukrainian].

14. Publius Ovidius Naso. (2020). Metamorfozy [The Metamorphoses]. (A. Sodomora, Trans.). Lviv: Vydavnytstvo "Apriori" [in Ukrainian].

15. Saienko, V. (2013). Z ukrainsko-skandynavskykh literaturnykh vzaiemyn: O. Kobylianska i Ye.-P. Yakobsen [From Ukrainian-Scandinavian literary relations: O. Kobylianska and E.-P. Jacobsen]. Slovo i Chas. 11. 19-Skoryna, L. (2019). Noise and echo: discourse of intertextuality in the Ukrainian literature of the 1920s. Cherkasy: BramaUkraina [in Ukrainian].

16. Nalyvaiko, D. (Ed). (2009). Suchasna literaturna komparatyvistyka: stratehii i metody. Antolohiia [Modern literary comparative studies: strategies and methods. Anthology]. Kyiv : Vydavnychyi dim "Kyievo-Mohylianska akademiia" [in Ukrainian].

17. Bakula, B. Morenets, V. (Ed.). (2008). Teoriia literatury v Polshchi. Antolohiia tekstiv. Druha polovyna XX pochatok XXI st. [Theory of literature in Poland. Anthology of texts. The second half of the XX - early XXI century]. (S. Yakovenko, Trans.). Kyiv : Vydavnychyi dim "Kyievo-Mohylianska akademiia" [in Ukrainian].

18. Foster, T. (2021). Kak chitat hudozhestvennuyu literaturu kak professor: Pronitsatelnoe rukovodstvo po chteniyu mezhdu strok [How to read novels like a professor]. (T.V. Kamyishnikova, M.P. Suhotina, Trans.). Moskva: KoLibri, Azbuka-Attikus [in Russian].

19. Franko, I. Tvory v 50 t. T. 50 [Works in 50 volumes. Vol. 50] [in Ukrainian].

20. Genette, G. (1999). Palimpsesty. Literatura druhoho rivnia [Palimpsests. Second level literature]. Teoriia i metodolohiia literaturoznavchykh doslidzhen. Varshava: Universytet Varshavskyi [in Polish]. 


\section{A. K. DYMOVSKA}

Candidate of Philological Sciences, Lecturer Subject Expert Commission for Ukrainian Philology, Municipal establishment "Balta Pedagogical Professional College”, Balta, Odesa region, Ukraine E-mail:annadymm@ukr.net https://orcid.org/0000-0002-1300-5463

\section{ON REMINISCENCES FROM HANS CHRISTIAN ANDERSEN "THE LITTLE MATCH GIRL” FAIRY TALE IN O. KOBYLIANSKA'S STORY “TSARIVNA”}

The article investigates intertextual inclusions from the fairy tale by Hans Christian Andersen "The Little Match Girl" in O. Kobylianska's story "Tsarivna". Given the writer's fascination with Danish literature, the assumption of the possibility of intertextual interaction and the feasibility of such parallels is made and substantiated (traditionally works by O. Kobylianska were studied in the context of German and Danish literatures, but without direct comparison with Hans Christian Andersen's texts). It was established that both texts are invariants of archetypal model of an orphan, the archaic origins of which reach folklore motif of the youngest daughter, which was later transformed in a European fairy tale into the image of a stepdaughter. It was found that the heroines of these works, in addition to identical social status, represent similar psychological types. It is determined that O. Kobylyanska's appeal to the archaic folklore-mythological image is conditioned by the author's psychological complexes and traumas, which, from the point of view of psychoanalysis, formed a special "melancholic context" of her work, associated with losses of beloved people, in particular. Mythological layers of the story "Tsarivna" (ancient myth of Narcissus and German legends about the mermaid Lorelei), the manifestations of which are found in the personal traits and patterns of behavior of Natalka Verkovych are analyzed, thus the reception of the motif of an orphan is deepened. Associative echoes between the analyzed works at the level of specific fragments of the text were found. The identified examples of typological kinship are interpreted as reminiscence in the understanding of unconscious or involuntary borrowing at the levels of image, motif, plot. In addition, not only similar, but also distinctive features of the poetics of the fairy tale by Hans Christian Andersen and O. Kobylianska's story, conditioned by non-identity of the authors' worldviews and intentions (existentialism of the Danish storyteller and the neo-romantic method of the pioneer of Ukrainian modernism), gender and possibly national specifics of understanding the issues raised in the analyzed works, are analyzed.

Key words: intertextuality, reminiscence, image, image, plot, motif, myth, archetype. 